\title{
アルミニウム合金の孔食電位を推定可能な自然電位測定条件
}

\author{
一般社団法人日本アルミニウム協会 耐食性評価試験委員会*
}

Journal of The Japan Institute of Light Metals, Vol. 67, No. 1 (2017), 16-19
(C) 2017 The Japan Institute of Light Metals

\section{Recommended measurement conditions of open-circuit potential of aluminum alloys in sake of estimation of pitting potential}

Japan Aluminium Association Corrosion Resistance Evaluation Committee*

Keywords: open-circuit potential; pitting potential; oxidant; statistical analysis; aluminum alloys

1. 緒言

アルミニウム合金およびその製品において使用上問題とな る腐食形態は孔食に代表される局部腐食である。孔食の起 こりやすさは孔食電位 (pitting potential, $E_{\mathrm{PIT}}$ ) として測定す ることができ, $E_{\mathrm{PIT}}$ 差を利用したカソード防食が, 航空機 ${ }^{1)}$, 熱交換器 ${ }^{2) \sim 6)}$, 配管 ${ }^{7)}$ 等に, 孔食の防食方法として常用さ れている。アルミニウム合金の $E_{\mathrm{PIT}}$ を決定するためのアノー ド分極曲線の測定条件については, 軽金属学会研究委員会 表面処理部会腐食防食分科会の報告書 ${ }^{8)}$ に詳述されている。 一方で，測定装置および手順がより簡便で，腐食に関する実 務経験の少ない方にも直感的に理解がしやすい自然電位（開 回路電位, open-circuit potential, $\left.E_{\mathrm{OC}}\right)$ を $E_{\mathrm{PIT}}$ に代用する場合 がある。この $E_{\mathrm{OC}}$ の測定条件に関しては，国内の各機関にお いても統一されておらず，同じ材料と環境の組合せでありな がら種々の測定值が報告されていることがあり， $E_{\mathrm{OC}}$ を各測 定機関が再現性よく測定できる方法の規格化が望まれる。こ うしたことから，一般社団法人日本アルミニウム協会耐食性 評価試験委員会では，再現性のよい $E_{\mathrm{PIT}}$ を簡便に得るために 必要な $E_{\mathrm{OC}}$ の測定条件について，6機関によるラウンドロビ ンテストを実施して検証し標準化を目指した。

\section{2. 実 験方法}

測定条件の規格化にあたっては測定誤差の小さい方法であ ることが要求される。ラウンドロビンテストは, 提示された

Table 1 The conditions for measuring open-circuit potential in round robin tests.

\begin{tabular}{l|l}
\hline \hline Specimen & A1100-H24 \\
\hline Solution & $\begin{array}{l}5 \text { mass\% } \mathrm{NaCl}+1 \mathrm{~mL} / \mathrm{L} \mathrm{CH} \mathrm{CHOH}_{3} \mathrm{COO} \\
\text { stirring } 60 \mathrm{rpm}) \\
5 \text { mass\% } \\
\text { stationary }\end{array}$ \\
\hline $\begin{array}{l}\text { Concentration of } \\
\text { source } \mathrm{CH}_{3} \mathrm{COOH}\end{array}$ & $>99.7$ mass $\%$ (JIS $\mathrm{CH}_{3} \mathrm{COOH}$, \\
\hline Temperature & $25^{\circ} \mathrm{C}$ or $\mathrm{RT}$ \\
\hline Aeration & No \\
\hline Pretreatment & $\begin{array}{l}5 \text { mass } \% \mathrm{NaOH}, 60^{\circ} \mathrm{C}, 30 \mathrm{~s} \rightarrow \text { deionized } \\
\text { water } \rightarrow 30 \mathrm{mass} \% \mathrm{HNO}_{3}, \mathrm{RT}, 60 \mathrm{~s} \rightarrow \\
\text { deionized water }\end{array}$ \\
\hline Time & $24 \mathrm{~h}$ \\
\hline Measurement & 1 point $/ \mathrm{min}$ \\
\hline Number & 4 \\
\hline
\end{tabular}

Table 2 The set up of equipment for measuring open-circuit potential in each organ verified by round robin tests.

\begin{tabular}{c|l|l|c|c|c|c}
\hline \hline & \multicolumn{1}{|c|}{ Equipment } & Reference electrode & Cell & $\begin{array}{c}\text { Salt } \\
\text { bridge }\end{array}$ & $\begin{array}{c}\text { Amount of water } \\
\left(\mathrm{mL} / \mathrm{cm}^{2}\right)\end{array}$ & Temperature \\
\hline A & HOKUTO-DENKO, HZ-3000 & DKK-TOA, HS-205C & Commercial product & Use & 600 & $25^{\circ} \mathrm{C}$, water bath \\
\hline B & HOKUTO-DENKO, HZ-5000 & DKK-TOA, HS-205C & $1 \mathrm{~L}$ beaker & Use & 500 & $25^{\circ} \mathrm{C}$, water bath \\
\hline C & HOKUTO-DENKO, HA-151A & DKK-TOA, HS-205C & Original cell & Use & 200 & $25^{\circ} \mathrm{C}$, air conditioner \\
\hline D & Solartron, SI-1286 & DKK-TOA, HS-305D6 & Original cell & Use & 200 & $25^{\circ} \mathrm{C}$, water bath \\
\hline E & HOKUTO-DENKO, HE-104A & DKK-TOA, HS-205C & $200 \mathrm{~mL}$ beaker & Disuse & 100 & $25^{\circ} \mathrm{C}$, water bath \\
\hline F & HOKUTO-DENKO, HA-150G & DKK-TOA, HS-205C & $1 \mathrm{~L}$ beaker & Disuse & 1000 & $25^{\circ} \mathrm{C}$, air conditioner \\
\hline
\end{tabular}

*大谷良行, 小山高弘, 兒島洋一 (株式会社 $\mathrm{UACJ}$ ), 岩尾祥平 (三菱アルミニウム株式会社), 小堀一博, 南 和彦 (昭和電工株式会社), 松門克浩（株式会社神戸製鋼所），紺野晃弘（一般財団法人日本ウエザリングテストセンター），長澤大介（日本軽金属株式会社），石川龍男 (一般社団法人日本アルミニウム協会)

受付日：平成28年7月 1 日 受理日：平成28年 10 月 20 日 
測定条件の信頼性の検証を目的として，複数の試験機関で同 一試料について測定を行う共同実験である。今回の $E_{\mathrm{OC}}$ 測定 条件に関して6機関 $(\mathrm{A} \sim \mathrm{F})$ で検討した。 $E_{\mathrm{OC}}$ 測定条件およ び各機関における $E_{\mathrm{OC}}$ 測定装置の構成を Table 1 および Table 2 にそれぞれ示す。供試材は，A1100-H24であり，同一ロット から切り出した試片について各機関で測定した。試験溶液 には，アルミニウム合金に対する促進腐食試験であるCASS, $\mathrm{SST}$ と同じく， $E_{\mathrm{PIT}}$ に与える影響の小さいままにカソード反 応の活性を増大できる $\mathrm{CH}_{3} \mathrm{COOH}$ を添加した $5 \mathrm{mass} \% \mathrm{NaCl}$ 水 溶液を使用した。本報で示す酢酸添加量は， $5 \mathrm{mass} \% \mathrm{NaCl}$ 水 溶液 $1 \mathrm{~L}$ あたりの，JIS K 8355 に規定する特級または同等以 上の $\mathrm{CH}_{3} \mathrm{COOH}$ の原液の添加量 $(\mathrm{mL})$ として, $\mathrm{mL} / \mathrm{L}$ で示す。 また， $E_{\mathrm{PIT}}$ を $E_{\mathrm{OC}}$ 測定と同じ供試材を用いて Table 3 に示す条 件で測定した。

\section{3. 実 験 結 果}

\section{1 ラウンドロビンテスト}

10-30 min, 30 min-1 h, 1-2h, 2-4h, 4-8h, 8-16h および 12-24h

Table 3 The conditions for measuring pitting potential

\begin{tabular}{l|l}
\hline \hline Specimen & A1100-H24 \\
\hline Area & $10 \mathrm{~mm} \times 10 \mathrm{~mm}$ \\
\hline Solution & $5 \mathrm{mass} \% \mathrm{NaCl}$, stationary \\
\hline Temperature & $25^{\circ} \mathrm{C}$ or $\mathrm{RT}$ \\
\hline Deaeration & Ar or $\mathrm{N}_{2}(100-200 \mathrm{~mL} / \mathrm{min})$ \\
\hline Pretreatment & $\begin{array}{l}5 \text { mass } \% \mathrm{NaOH}, 60^{\circ} \mathrm{C}, 30 \mathrm{~s} \rightarrow \text { deionized } \\
\text { water } \rightarrow 30 \mathrm{mass} \% \mathrm{HNO}_{3}, \mathrm{RT}, 60 \mathrm{~s} \rightarrow \\
\text { deionized water }\end{array}$ \\
\hline Immersion time & $30 \mathrm{~min}$ \\
\hline Sweep rate & $0.33 \mathrm{mV} / \mathrm{s}$ \\
\hline Measurement & $1 \mathrm{point} / \mathrm{min}$ \\
\hline Number & 2 \\
\hline
\end{tabular}

のそれぞれの期間の $E_{\mathrm{OC}}$ を Fig. 1 に示す。各機関のデータに おいて，各プロットは $n=4$ の算術平均值で，そこにそれぞれ の上下限值をエラーバーで示している。さらに，全機関の算 術平均值を合せて示した。全機関の算術平均值の経時变化は 小さく，浸漬初期から安定した值を示した。

\subsection{JIS Z 8402 による統計解析}

Fig. 1 に示した 6 機関， $n=4$ の $E_{\mathrm{OC}}$ の值をJIS Z 8402 に準拠 して解析した結果を Table 4 に示す。解析により得られた項 目は，全機関算術平均值，機関内標準偏差，機関間標準偏差， Cochran検定に用いるC統計量，およびGrubbs検定に用いる $\mathrm{T}$ 統計量である。Cochran検定では，C統計量が，試験機関 数 $6, n=4$ における危険率 $1 \%$ および $5 \%$ の较却限界值である 0.626 および 0.532 を超えない場合を合格, 超えた場合を不合 格とする。Grubbs 検定では, T 統計量が, 試験機関数 $6, n=4$ における危険率 $1 \%$ および $5 \%$ の裹却限界值である 1.944 およ び1.822を超えない場合を合格，超えた場合を不合格とする。 Table 4 中には，こうした合否を色分けで示している。

Table 4 に示した $E_{\mathrm{OC}}$ に関する各検定值の合否を $\bigcirc \times$ で表し Table 5 に示す。脱気した $5 \mathrm{mass} \% \mathrm{NaCl}$ 水溶液における $E_{\mathrm{PIT}}$ の全機関による測定值の算術平均值は, $-695.2 \mathrm{mV}$ あっ た。これと $E_{\mathrm{OC}}$ の算術平均值との差も, Table 5 に合せて示す。 Cochran検定およびGrubbs 検定の合否には経時的な傾向は認 められず，長時間側で不合格となる場合もあった。 $5 \mathrm{mass} \%$ $\mathrm{NaCl}+1 \mathrm{~mL} / \mathrm{L} \mathrm{CH}_{3} \mathrm{COOH}$ 試験溶液，攪拌ありの方が， $5 \mathrm{mass} \%$ $\mathrm{NaCl}+15 \mathrm{~mL} / \mathrm{L} \mathrm{CH}_{3} \mathrm{COOH}$ 試験溶液, 液静止よりも検定が合 格となる場合が多かった。これは，攪拌によって $\mathrm{CH}_{3} \mathrm{COOH}$

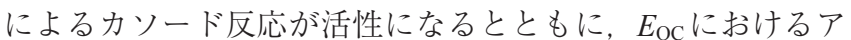
ノード反応とカソード反応の進行に伴う試料電極近傍の液性 の変化が軽減されたことが一因であると推察される。 $E_{\mathrm{OC}}$ と $E_{\mathrm{PIT}}$ との差は, 経時的に減少する傾向にあったが，いずれも $10 \mathrm{mV}$ 未満であった。

\section{3 推奨測定条件}

Table 5 にまとめた結果を， $E_{\mathrm{OC}}$ 測定に求められる以下の 3 つの基準と照合した。基準は，(1)測定機関によらず再現性が
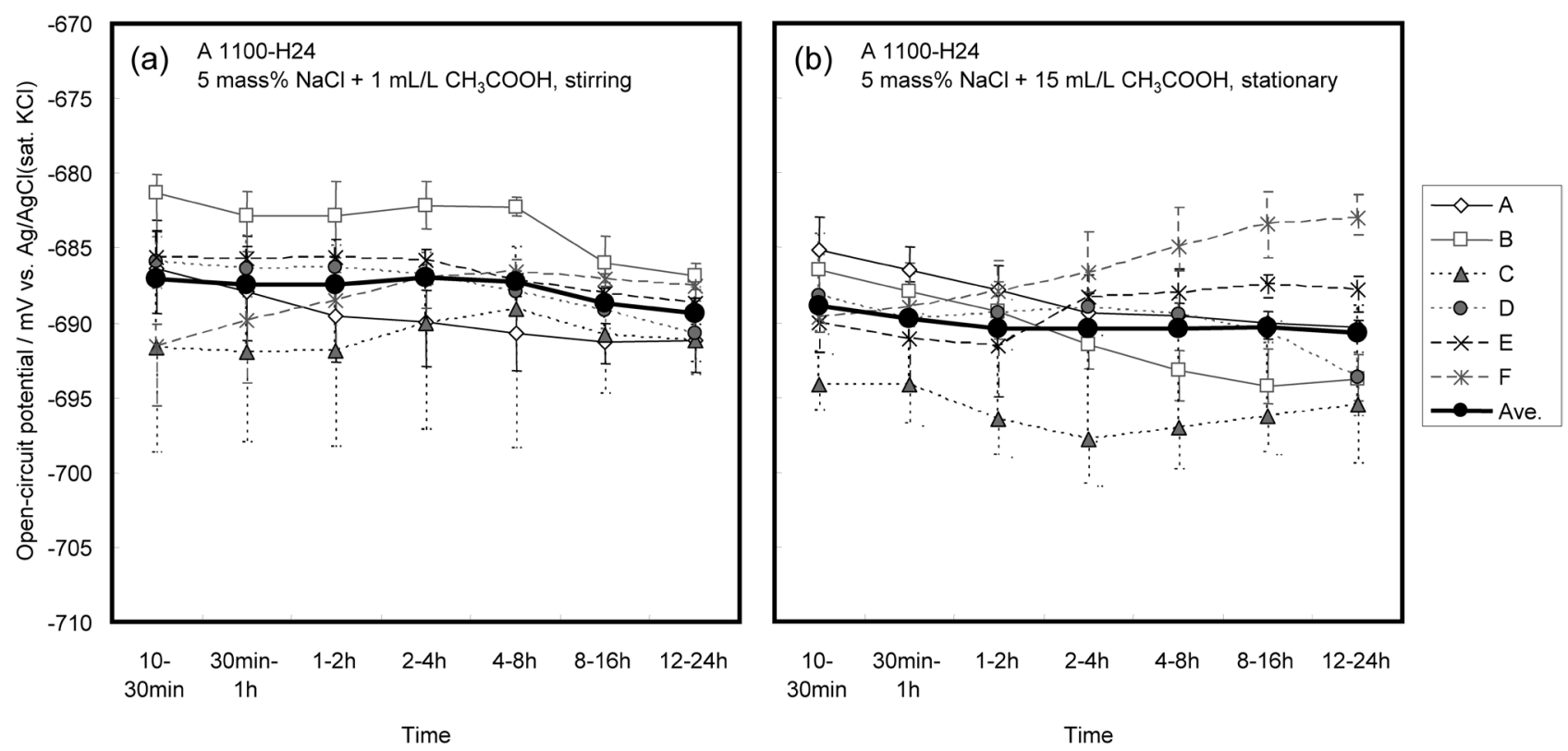

Fig. 1 Time dependence of open-circuit potentials in round robin tests. 
Table 4 Summary of statistical values on open-circuit potential and evaluated values.

\begin{tabular}{|c|c|c|c|c|c|c|c|c|}
\hline \multicolumn{2}{|c|}{ Time } & $10-30 \mathrm{~min}$ & $30 \mathrm{~min}-1 \mathrm{~h}$ & $1-2 \mathrm{~h}$ & $2-4 h$ & $4-8 h$ & $8-16 \mathrm{~h}$ & $12-24 h$ \\
\hline \multirow{5}{*}{$\begin{array}{l}\mathrm{A} 1100-\mathrm{H} 24 \\
5 \mathrm{mass} \% \mathrm{NaCl}+ \\
1 \mathrm{~mL} / \mathrm{L} \mathrm{CH} \mathrm{CHOH}_{3} \mathrm{COOH} \\
\text { stirring }\end{array}$} & Arithmetic mean & -687.096 & -687.450 & -687.459 & -686.974 & -687.310 & -688.733 & -689.381 \\
\hline & $\begin{array}{l}\text { Standard deviation in } \\
\text { a single organ }\end{array}$ & 2.946 & 2.858 & 2.674 & 2.396 & 2.780 & 1.554 & 1.564 \\
\hline & $\begin{array}{l}\text { Standard deviation in } \\
\text { a group }\end{array}$ & 4.213 & 3.521 & 3.467 & 3.167 & 3.186 & 2.221 & 2.083 \\
\hline & C statistic & 0.514 & 0.407 & 0.520 & 0.702 & 0.864 & 0.571 & 0.406 \\
\hline & T statistic & 1.453 & 1.438 & 1.438 & 1.628 & 1.745 & 1.311 & 1.273 \\
\hline \multirow{5}{*}{$\begin{array}{l}\mathrm{A} 1100-\mathrm{H} 24 \\
5 \mathrm{mass} \% \mathrm{NaCl}+ \\
15 \mathrm{~mL} / \mathrm{L} \mathrm{CH}_{3} \mathrm{COOH} \\
\text { stationary }\end{array}$} & Arithmetic mean & -688.942 & -689.759 & -690.401 & -690.446 & -690.389 & -690.360 & -690.686 \\
\hline & $\begin{array}{l}\text { Standard deviation in } \\
\text { a single organ }\end{array}$ & 1.896 & 1.914 & 2.147 & 2.443 & 2.163 & 2.100 & 2.222 \\
\hline & $\begin{array}{l}\text { Standard deviation in } \\
\text { a group }\end{array}$ & 3.295 & 2.857 & 3.450 & 4.120 & 4.369 & 4.713 & 4.800 \\
\hline & C statistic & 0.369 & 0.439 & 0.389 & 0.626 & 0.636 & 0.710 & 0.708 \\
\hline & T statistic & 1.655 & 1.654 & 1.858 & 1.876 & 1.584 & 1.498 & 1.643 \\
\hline
\end{tabular}

$\square$ : accepted (failure rate $5 \%$ ), $\square$ : accepted (failure rate $1 \%$ ), $\square$ : rejected (failure rate $1 \%$ ).

Table 5 Summary of judgments against the measurement conditions of open-circuit potentials by JIS Z 8402 and difference between the open-circuit potential and the pitting potential.

\begin{tabular}{|c|c|c|c|c|c|c|c|c|c|}
\hline \multicolumn{3}{|c|}{ Time } & $10-30 \mathrm{~min}$ & $30 \mathrm{~min}-1 \mathrm{~h}$ & $1-2 \mathrm{~h}$ & $2-4 h$ & $4-8 \mathrm{~h}$ & $8-16 \mathrm{~h}$ & $12-24 \mathrm{~h}$ \\
\hline \multirow{2}{*}{ A1100-H24 } & \multirow{2}{*}{ Cochran's test } & Failure rate $1 \%$ & $\bigcirc$ & $\bigcirc$ & $\bigcirc$ & $x$ & $\times$ & $\bigcirc$ & $\bigcirc$ \\
\hline & & Failure rate $5 \%$ & $\bigcirc$ & $\bigcirc$ & $\bigcirc$ & $\times$ & $x$ & $\times$ & O \\
\hline \multirow{3}{*}{$\begin{array}{l}5 \text { mass } \% ~ N a C l+ \\
1 \mathrm{~mL} / \mathrm{L} \mathrm{CH}_{3} \mathrm{COOH} \\
\text { stirring }\end{array}$} & \multirow{2}{*}{ Grubbs' test } & Failure rate $1 \%$ & $\bigcirc$ & $\bigcirc$ & O & $\bigcirc$ & $\bigcirc$ & O & $\bigcirc$ \\
\hline & & Failure rate $5 \%$ & $\bigcirc$ & $\bigcirc$ & $\bigcirc$ & $\bigcirc$ & $\bigcirc$ & $\bigcirc$ & $\bigcirc$ \\
\hline & \multicolumn{2}{|c|}{ Difference with $E_{\mathrm{PIT}}$ in $5 \% \mathrm{NaCl}(\mathrm{mV})$} & 8 & 8 & 8 & 8 & 8 & 6 & 6 \\
\hline \multirow{2}{*}{ A1100-H24 } & \multirow{2}{*}{ Cochran's test } & Failure rate $1 \%$ & $\bigcirc$ & $\bigcirc$ & 0 & $\times$ & $\times$ & $\times$ & $x$ \\
\hline & & Failure rate $5 \%$ & 0 & $\bigcirc$ & 0 & $\times$ & $\times$ & $\times$ & $\times$ \\
\hline \multirow{3}{*}{$\begin{array}{l}5 \text { mass } \% ~ \mathrm{NaCl}+ \\
15 \mathrm{~mL} / \mathrm{L} \mathrm{CH}_{3} \mathrm{COOH} \\
\text { stationary }\end{array}$} & \multirow{2}{*}{ Grubbs' test } & Failure rate $1 \%$ & $\bigcirc$ & $\bigcirc$ & $\bigcirc$ & $\bigcirc$ & $\bigcirc$ & $\bigcirc$ & $\bigcirc$ \\
\hline & & Failure rate $5 \%$ & 0 & $\bigcirc$ & $\times$ & $\times$ & $\bigcirc$ & $\bigcirc$ & $\bigcirc$ \\
\hline & \multicolumn{2}{|c|}{ Difference with $E_{\mathrm{PIT}}$ in $5 \% \mathrm{NaCl}(\mathrm{mV})$} & 6 & 5 & 5 & 5 & 5 & 5 & 4 \\
\hline
\end{tabular}

$\bigcirc$ : accepted, $\times$ : rejected.

Table 6 Recommended measurement conditions of opencircuit potential based on results of round robin tests.

\begin{tabular}{l|l}
\hline \hline Solution & $\begin{array}{l}5 \text { mass } \% \mathrm{NaCl}+1 \mathrm{~mL} / \mathrm{L} \mathrm{CH}_{3} \mathrm{COOH}, \text { stirring } \\
(60 \mathrm{rpm})\end{array}$ \\
\hline Temperature & $25^{\circ} \mathrm{C}$ or $\mathrm{RT}$ \\
\hline Aeration & $\mathrm{No}$ \\
\hline Pretreatment & $\begin{array}{l}5 \mathrm{mass} \% \mathrm{NaOH}, 60^{\circ} \mathrm{C}, 30 \mathrm{~s} \rightarrow \text { deionized } \\
\text { water } \rightarrow 30 \text { mass } \% \mathrm{HNO}_{3}, \mathrm{RT}, 60 \mathrm{~s} \rightarrow \\
\text { deionized water }\end{array}$ \\
\hline Time & 30 min $-1 \mathrm{~h}$ \\
\hline Measurement & More than 1 point $/ \mathrm{min}$ \\
\hline
\end{tabular}

よい（Cochran検定およびGrubbs検定に合格する）こと，(2) $5 \mathrm{mass} \% \mathrm{NaCl}$ 水溶液における $E_{\mathrm{PIT}}$ との差が小さいこと, (3) 測定時間が短いこと, である。ラウンドロビンテストは, $\mathrm{A} 3003-\mathrm{O}$, および $600^{\circ} \mathrm{C}, 3 \min$ のろう付相当加熱を施した A4045/A3003ブレージングシートのA4045面でも実施してい
る。これらの結果も踏まえ推奨条件を選定した。(1)の基準か ら，検定に合格する場合の多い試験溶液条件として $5 \mathrm{mass} \%$ $\mathrm{NaCl}+1 \mathrm{~mL} / \mathrm{L} \mathrm{CH}_{3} \mathrm{COOH}$ 試験溶液，攪拌ありを選定した。(2) の基準である電位差はすべて $10 \mathrm{mV}$ 未満で，いずれの測定条 件でも問題ないと判断した。(3)基準から, 検定がすべて合 格となる最も短い時間として, 測定時間は $30 \mathrm{~min}-1 \mathrm{~h}$ とした。 以上のように導いたアルミニウム合金の $E_{\mathrm{OC}}$ の推奨測定条件 をTable 6に示す。ただし，攪拌機がない場合への対応とし て, $15 \mathrm{~mL} / \mathrm{L} \mathrm{CH}_{3} \mathrm{COOH}$, 液静止という条件でも許容できる 測定值が得られる場合が多いことを付記する。また, 測定回 数を多くすることは， $E_{\mathrm{PIT}} に よ り$ 近い $E_{\mathrm{OC}}$ を得ることに寄与 する。

本推奨条件は, A1100-H24, A3003-O, 万う付相当加熱を施 したA4045/A3003ブレージングシートのA4045 面での検討か ら選定した。高純度アルミニウムなどを除き多くのアルミニ ウム合金のカソード反応の活性は, 条件を選定したアルミニ ウム合金と同等もしくはそれ以上と推察される ${ }^{9)}$ ため, ア ルミニウム合金の種類を問わず，本推奨条件は適用できると 
考えられる。

\section{4. おわりに}

アルミニウムおよびアルミニウム合金の耐食性を評価する ために， $E_{\mathrm{PIT}}$ 近傍にある $E_{\mathrm{OC}}$ を測定する「自然電位測定条件」 を6機関によるラウンドロビンテストで検証して推奨条件を 選定した。本検討に関する詳細は投稿予定の別報をご参照い ただきたい。推奨条件に基づいた標準を作成予定である。活 用いただければ幸いである。

\section{参 考 文 献}

1）磯野英二：軽金属，10（1960），341-347.
2) 福井利安, 入江 宏, 木村 聰, 田部善一：軽金属, 29 (1975), 410-417.

3）川瀬 寛, 山口元由, 石川和徳：軽金属, 29（1975），505-512.

4) 多田清志, 小堀一博, 植木光彦：軽金属, 52 (2002), 269-275.

5) 吉野路英, 江戸正和, 麻野雅三 : 軽金属, 58 (2008)，279-284.

6) 本川幸䈳, 水谷高大, 兒島洋一, 興戸正純：軽金属, 61 (2011), 383-388.

7）軽金属協会 海水淡水化委員会：軽金属, 25（1975）， 392-401.

8) 軽金属学会 研究委員会 表面処理部会腐食防食分科会編：アル ミニウム及びアルミニウム合金の電気化学的分極測定, 軽金属 学会, (1985).

9) 原 康人, 大谷良行, 兒島洋一：軽金属学会第 118 回春期大会 講演概要, (2010), 295-296. 